\title{
Filosofi Penataan Ruang Spasial Vertikal Pada Rumah Tradisional Saoraja Lapinceng Kabupaten Barru
}

\author{
Wasilah $^{1}$, A. Hildayanti² \\ ${ }^{1}$ Dosen Tetap, Fakultas Sains dan Teknologi Jurusan Teknik Arsitektur UIN Alauddin Makassar \\ ${ }^{2}$ Dosen Tetap, Fakultas Sains dan Teknologi Jurusan Teknik Aritektur UIN Alauddin Makassar \\ wasilah@uin-alauddin.ac.id
}

\begin{abstract}
ABSTRAK
Rumah tradisional Bugis secara vertikal pada umumnya dibagi atas tiga bagian yakni kepala, badan, dan kaki rumah. Ketiga bagian ini memiliki fungsi dan filosofi yang berbeda tetapi menjadi satu kesatuan yang saling bersinergi. Dalam bidang arsitektural, filosofi berperan sebagai penentu kebijakan pembagian ruang spasial pada bangunan. Utamanya pada bangunan tradisional seperti Saoraja Lapinceng di Kabupaten Barru yang memiliki beragam filosofi dan pesan yang bermakna yang dihasilkan dari penafsiran masyarakat terhadap fenomena alam dan adat istiadat yang berkembang didaerah tersebut. Namun pada zaman modernisasi, sebagian besar masyarakat belum mengetahui filosofi yang diterapkan pada Saoraja Lapinceng. Oleh karena itu, penelitian deskriptif ini akan mengidentifikasi berbagai filosofi yang terkandung dalam setiap pembagian ruang spasial secara vertikal pada Saoraja Lapinceng. Melalui teknik analisa diachronic reading yaitu metode penelusuran jejak sejarah dan faham yang berlaku di Kabupaten Barru, maka diketahui bahwa masyarakat Bugis Barru membagi ruang secara vertikal menjadi tiga bagian, yaitu "rakkeang" atau bagian atas rumah berfungsi sebagai tempat tinggal penghuni perempuan melambangkan golongan yang ditinggikan, "ale bola" atau bagian tengah berfungsi sebagai tempat tinggal penghuni laki-laki melambangkan penguasa dan pemegang kendali, dan "awa bola" atau bagian bawah berfungsi sebagai tempat penyimpanan peralatan kerja penghuni rumah melambangkan kaki dan penggerak.
\end{abstract}

Kata kunci: Bugis, filosofi ruang, ruang spasial vertikal, rumah tradisional.

\section{ABSTRACT}

Bugis vertically traditional house is generally divided into three parts: head, body and leg home. The third part has a function and a different philosophy but as one that in synergy. In the field of architectural, philosophy plays a decisive role in the spatial distribution of building space. Mainly in traditional buildings such as Saoraja Lapinceng in Barru which has a variety of philosophical and meaningful messages resulting from the interpretation of the community against natural phenomena and customs that developed in the area. But in the days of modernization, most people do not know the philosophy applied to Saoraja Lapinceng. Therefore, this descriptive study will identify various philosophies contained in each division of the spatial space vertically on Saoraja Lapinceng. Through analysis techniques diachronic reading is a search method traces the history and ideology prevailing in Barru, it is known that the Bugis Barru divide the space vertically into three parts, namely "rakkeang" or the top of the house serves as a place to stay occupant of women symbolizing the group elevated, "ale bola" or the middle part serves as a male occupant symbolize authority and in controler, and "awa bola" or bottom serves as a storage area residents working equipment symbolizes foot and driving.

Keywords: Bugis, philosophy of space, vertical spatial space, traditional home. 


\section{Pendahuluan}

Rumah tradisional merupakan salah satu peninggalan arsitektur tradisional yang mencerminkan gagasan dan perilaku masyarakat pendukungnya dan berkenaan dengan penataan pemanfaatan ruang dalam memenuhi kebutuhan ruang masyarakat. Tuntutan manusia terhadap rumah meliputi pemenuhan kebutuhan fisik yang statis dan menjadi wadah pengembangan diri. Namun, rumah di Sulawesi Selatan lebih dari sekedar tempat berteduh bagi penghuninya, atau objek materil yang indah dan menyenangkan. Rumah adalah ruang sakral di mana orang lahir, kawin dan meninggal dan di tempat ini pula kegiatan-kegiatan sosial dan ritual tersebut diadakan. Hal ini dikarenakan masyarakat Bugis menggambarkan makna kehidupan melalui nilai tradisi. Nilai tradisi setiap daerah sebagian besar berbeda, dikarenakan sudut pandang dan penafsiran pesan alam oleh masyarakat juga berbeda. Sejalan dengan teori Lang (1994) yakni setiap desain dalam setiap lingkungan binaan adalah sumber potensi untuk mengirimkan pesan.

Dalam masyarakat Bugis, adat istiadat menjadi pedoman dalam berpikir dan bertindak sesuai pola kehidupan masyarakat. Adat istiadat bersifat mengatur dan mengarahkan baik tingkah laku, cara berinteraksi, dan penentuan tata cara membangun rumah dan membagi ruang berdasarkan kebutuhan ruang penghuninya. Adat istiadat dan kepercayaan adalah warisan nenek moyang yang mengisi inti kebudayaan. Transformasi adat istiadat dan kepercayaan dapat dikemukakan dalam bentuk fisik rumah tradisional. Setiap rumah tradisional memiliki bentuk, tata ruang spasial, ornamen, dan sebagainya yang berbeda. Hal ini disebabkan adat istiadat dan kepercayaan nenek moyang masyarakat berbeda pula.

Meskipun suku Bugis memiliki adat istiadat yang sama, akan tetapi sistem kepercayaan yang dianut oleh masyarakat sebagian besar tidaklah sama. Hal ini dibuktikan dengan filosofi penataan ruang spasial yang dianut oleh masyarakat Bugis di Kabupaten Barru. Rumah tradisional Bugis, memiliki makna simbolis sekaligus memiliki sisi fungsional didalamnya. Secara horisontal, pembagian ruang spasial Saoraja Lapinceng identik dengan pembagian ruang rumah tradisional Bugis lainnya. Berbeda dengan pembagian ruang spasial secara vertikal, yang didasarkan pada kosmologi mikrokosmos yaitu pembagian rumah Bugis dibagi pula atas tiga tingkatan, yaitu: Rakkeang (loteng, kepala), Alle Bola (badan rumah), dan Awa Bola (kolong rumah, kaki).

Pandangan tiga tingkat rumah Bugis ini, sebagai bentuk ekspresi penyembahan kepada tiga dewa yang menguasai tiga dunia dalam pandangan Bugis. Ketiga dewa itu adalah: Dewa Langi, yaitu dewa yang menguasai langit, Dewa Malino yaitu dewa yang menguasai bumi dengan segala isinya, dan Dewa UwaE yang menguasai tanah, sungai, dan laut (Yunus, 1999). Ketiga dewa ini merupakan dewa yang dihormati oleh suku Bugis dan dipercaya hubungan yang terjalin dengan baik antara umat dengan dewa akan aman dan sejahtera. Sebaliknya apabila hubungan baik itu hancur akibat kesalahan manusia kan disusul oleh azab yang nampak dalam bencana alam, wabah, gempa bumi, kemarau panjang dan lain-lain. Oleh karena itu, agar hubungan umat dengan dewa tetap baik, maka perlu ada tata laku penyembahan kepada tiga dewa tersebut.

Dalam rumah Bugis penyembah Dewa Langi' diadakan di loteng rumah (rakkeang) dengan sesajen. Rakkeang sebagai tempat yang tertinggi. Penyembahan Dewa Malino dianggap berdiam di Ale Bola (badan rumah) juga dalam bentuk sesajen. Begitu pun Dewa Uwa E, penyembahannya dalam bentuk sesajen dan dianggap bersemanyam di Awa Bola (kolong rumah). Berbeda dengan rumah Bugis pada umumnya, pada Saoraja Lapinceng acara penyembahan terhadap ketiga dewa tersebut diadakan di Ale Bola (badan rumah) karena ruang sakral untuk penyembahan telah disediakan khusus di ruangan ini. 
Perbedaan tersebut menjadikan Saoraja Lapinceng dipilih sebagai objek penelitian dengan memfokuskan objek kajian pada filosofi pembagian ruang spasial Saoraja Lapinceng secara vertikal. Hal ini bertujuan untuk mengidentifikasi nilai tradisi atau filosofi yang mengalami perbedaan tersebut, sehingga mampu menambah dan memperkaya kearifan lokal di Sulawesi Selatan, utamanya pada arsitektur tradisional Suku Bugis.

\section{Bahan dan Metode}

Penelitian ini ditunjang oleh landasan teori yang relevan seperti arsitektur tradisional, hakekat ruang, konsep ruang dan waktu, serta rumah adat tradisional Bugis. Landasan teori tersebut dirangkum pada sub bahasan bahan. Sedangkan untuk metode penelitian yang digunakan dibagi atas jenis penelitian dan teknik analisa yang digunakan.

\subsection{Bahan}

\subsubsection{Arsitektur Tradisional Sebagai Bahasa Rakyat}

Menurut Amos Rapoport (1960), Arsitektur tradisional merupakan bentukan arsitektur yang diturunkan dari satu generasi ke generasi berikutnya. Mempelajari bangunan tradisional berarti mempelajari tradisi masyarakat yang lebih dari sekadar tradisi membangun secara fisik. Masyarakat tradisional terikat dengan adat yang menjadi konsesi dalam hidup bersama.

Arsitektur tradisional merupakan perwujudan dari bahasa tradisional karena setiap bagian dari bangunan tradisional mengandung arti tertentu, tergantung pada faham yang dianut oleh masyarakat setempat. Adat istiadat dan kepercayaan adalah warisan nenek moyang yang mengisi inti kebudayaan. Hal tersebut dipercaya sebagai warisan yang diterima langsung secara turun temurun. Terjadinya perbedaan cara penafsiran fenomena-fenomena alam oleh masyarakat menyebabkan munculnya gaya bangunan yang berbeda disetiap daerah. Perbedaan inilah yang melahirkan identitas lokal daerah.

Setiap goresan, bentuk, hingga penentuan fungsi ruang memiliki makna yang menyiratkan pesan sosial dan budaya kepada masyarakatnya. Selain itu, makna yang terkandung dalam setiap goresan seni ruang dan ornamen bangunan mampu mencirikan dan mendeskripsikan karakter penghuni bangunan tersebut. Sehingga seni bangunan tradisional atau arsitektur tradisional dapat dikategorikan sebagai bahasa rakyat.

\subsubsection{Hakekat Ruang}

Ruang dipahami sebagai sebuah wadah untuk melakukan suatu kegiatan tertentu dan berguna dengan baik bagi para pelakunya (masyarakat), serta berfungsi dalam kaitannya dengan kehidupan masyarakat tersebut. Suparlan (1999) menyebutkan bahwa "sebuah satuan tata ruang yang paling baku yang selalu ada dalam kehidupan manusia di masyarakat manapun adalah rumah". Oleh karena itu, ruang menjadi satu kebutuhan pokok manusia agar dapat melakukan segala kegiatan dengan baik dan terhindar dari gangguan-gangguan lingkungan secara fisik maupun non fisik. Hakekat ruang menjadi satu hal yang harus dimengerti dan dipahami sesuai dengan fungsi dan penghuninya. Dengan demikian ruang itu tercipta dari cerminan kondisi, setting dan waktu dimana ruang itu berada.

\subsubsection{Konsep Ruang dan Waktu}

Konsep ruang, meliputi : 
1. Ruang adalah konsep yang paling melekat dengan waktu.

2. Ruang merupakan tempat terjadinya berbagai peristiwa - peristiwa sejarah dalam perjalanan waktu.

3. Penelaahan suatu peristiwa berdasarkan dimensi waktunya tidak dapat terlepaskan dari ruang waktu terjadinya peristiwa tersebut.

4. Jika waktu menitik beratkan pada aspek kapan peristiwa itu terjadi, maka konsep ruang menitikberatkan pada aspek tempat, dimana peristiwa itu terjadi.

Konsep waktu, meliputi :

1. Masa lampau itu sendiri merupakan sebuah masa yang sudah terlewati. Tetapi, masa lampau bukan merupakan suatu masa yang final, terhenti, dan tertutup.

2. Masa lampau itu bersifat terbuka dan berkesinambungan. Sehingga, dalam sejarah, masa lampau manusia bukan demi masa lampau itu sendiri dan dilupakan begitu saja, sebab sejarah itu berkesinambungan apa yang terjadi dimasa lampau dapat dijadikan gambaran bagi kita untuk bertindak dimasa sekarang dan untuk mencapai kehidupan yang lebih baik di masa mendatang.

3. Sejarah dapat digunakan sebagai modal bertindak di masa kini dan menjadi acuan untuk perencanaan masa yang akan datang.

4. Keterkaitan konsep ruang dan waktu dalam sejarah

5. Konsep ruang dan waktu merupakan unsur penting yang tidak dapat dipisahkan dalam suatu peristiwa dan perubahannya dalam kehidupan manusia sebagai subyek atau pelaku sejarah.

Oleh karena itu, segala aktivitas manusia pasti berlangsung bersamaan dengan tempat dan waktu kejadian. Manusia selama hidupnya tidak bisa dilepaskan dari unsur tempat dan waktu karena perjalanan manusia sama dengan perjalanan waktu itu sendiri pada suatu tempat dimana manusia hidup (beraktivitas). Sehingga terdapat antara manusia, waktu dan tempat memiliki hubungan yang relevan.

\subsubsection{Rumah Tradisional Bugis}

Rumah adat suku Bugis dapat dibedakan berdasarkan status sosial penghuninya, beberapa diantaranya meliputi :

1. Saoraja (Sallasa) berarti rumah besar yang dihuni oleh keturunan raja (kaum bangsawan) dan,

2. Bola adalah rumah yang dihuni oleh rakyat biasa.

Tipologi kedua rumah ini adalah rumah panggung, lantainya mempunyai jarak tertentu dengan tanah, bentuk denahnya sama yaitu empat persegi panjang. Perbedaannya terlihat pada ukuran bangunan, tiang penyangga, bentuk atap sebagai penutup bubungan yang biasa disebut "timpak laja" yang bertingkat-tingkat antara tiga sampai lima sesuai dengan kedudukan penghuninya.

Rumah Bugis memiliki keunikan tersendiri, dibandingkan dengan rumah panggung dari suku yang lainnya. Bentuknya yang memanjang ke belakang dengan tambahan ruang disamping bangunan utama dan bagian depan yang disebut dengan lego-lego.

Berdasarkan pembagian ruang spasial secara vertikal, rumah tradisional Bugis dibagi menjadi 3 ruang, yaitu:

1) "Rakkeang" (loteng rumah), adalah bagian diatas langit-langit (eternit). Dahulu biasanya digunakan untuk menyimpan padi yang baru di panen.

2) "Ale bola" (badan rumah), adalah badan rumah yang terdiri dari lantai dan dinding yang terletak antara lantai dan loteng. Pada bagian ini terdapat ruanganruangan yang dipergunakan dalam aktivitas sehari-hari seperti menerima tamu, 
tidur, bermusyawarah, dan berbagai aktifitas lainnya. Badan rumah tediri dari beberapa bagian rumah seperti: Lotang risaliweng yang terdapat dibagian depan badan rumah berfungsi sebagai ruang menerima tamu, tempat tidur tamu, tempat bermusyawarah, tempat menyimpan benih, tempat membaringkan mayat sebelum dibawa ke pemakaman.

3) "Awa bola" (kolong rumah), adalah kolong yang terletak pada bagian bawah, yakni antara lantai dengan tanah. Kolong ini biasa pada zaman dulu dipergunakan untuk menyimpan alat pertanian, alat berburu, alat untuk menangkap ikan dan hewanhewan peliharaan yang di pergunakan dalam pertanian.

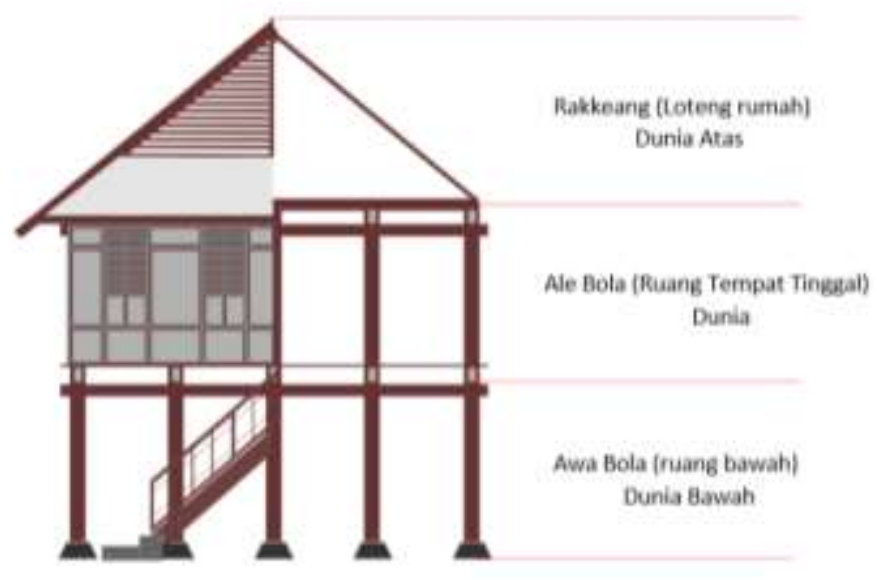

Gambar 1. Pembagian ruang spasial rumah tradisional Bugis (Sumber: http://kasuwiyang9.blogspot.co.id, 2011)

Sedangkan pembagian ruang spatial secara horisontal, dikelompokkan dalam tiga bagian sebagai berikut :

1. "Lontang risaliweng" (ruang depan)

Sifat ruang semi private, berfungsi sebagai tempat menerima tamu, tempat tidur tamu, tempat bermusyawarah, tempat menyimpan benih dan tempat membaringkan mayat sebelum dikebumikan. Ruang ini menjadi tempat berkomunikasi dengan orang luar yang sudah diizinkan untuk masuk. Sebelum memasuki ruang ini orang luar diterima lebih dahulu di ruang transisi (tamping).

2. "Lontang retengngah" (latte retengngah) atau ruang tengah.

Sifat ruang private, berfungsi untuk tempat tidur kepala keluarga dan anak-anak yang belum dewasa, tempat makan, dan melahirkan. Suasana kekeluargaan dengan rangkaian kegiatan informal keluarga pada ruang ini sangat kental.

3. "Lontang rilaleng" (latte rilaleng), sifat sangat private.

Fungsi ruang ini untuk tempat tidur anak gadis atau nenek/kakek. Anggota keluarga dianggap sebagai orang yang perlu perlindungan dari seluruh keluarga.

Untuk Sao raja, ada tambahan dua ruangan lagi yakni :

1. "Lego-lego"

Biasanya difungsikan sebagai tempat duduk tamu sebelum masuk.

2. "Dapureng"

Biasanya diletakkan di belakang atau samping. Fungsinya untuk memasak dan menyimpan peralatan masak.Paragraf hendaknya mengikuti 
format justify di kedua sisi dengan satu kali ketukan tab untuk alinea pertama. Gunakan jarak satu spasi di seluruh dokumen. Tidak perlu ada penambahan jarak (spasi) pada setiap pergantian paragraf.

\subsection{Metode}

Penelitian ini menggunakan metode penelitian deskriptif kualitatif yaitu metode yang mempelajari masalah-masalah dalam masyarakat serta tatacara yang berlaku dalam masyarakat serta situasi-situasi tertentu, termasuk tentang hubungan, kegiatan-kegiatan, sikap-sikap, pandangan-pandangan, serta proses-proses yang sedang berlangsung dan pengaruh-pengaruh dari suatu fenomena. Hal ini sejalan dengan pandangan Whintney (1960), dimana metode deskriptif adalah pencarian fakta dengan interpretasi yang tepat. Oleh karena itu, penelitian ini akan mengidentifikasi dan menggambarkan filosofi penataan ruang spasial secara vertikal Saoraja Lapinceng sesuai dengan adat istiadat dan nilai tradisi yang berlaku di Kabupaten Barru selaku lokasi objek penelitian. Dalam melengkapi proses identifikasi maka metode penelitian ini akan ditunjang dengan teknik pengumpulan data berupa observasi, wawancara dan dokumentasi visual.

Observasi dilakukan untuk memperoleh data menyeluruh mengenai Saoraja Lapinceng dan adat istiadat yang berlaku didaerah tersebut. Wawancara dilakukan untuk mengetahui sejarah dan makna yang terkandung tiap pembagian ruang pada Saoraja Lapinceng. Sedangkan dokumentasi dilakukan untuk menunjukkan bukti hasil observasi lapangan agar penelitian yang dilakukan tampak lebih riil.

Setelah data terkumpul, dilakukan penyusunan data secara sistematis untuk selanjutnya dianalisis secara deskriptif dengan menggunakan teknik analisis diachronic reading. Teknik analisa diachronic reading adalah salah satu teknik menganalisis objek penelitian melalui eksplorasi jejak sejarah melalui bukti-bukti fisik maupun wawancara kepada pemangku adat atau orang yang mengetahui jejak sejarah yang terjadi pada lokasi tersebut. Sehingga dihasilkan berbagai bukti sejarah yang mampu mendeskripsikan filosofi penataaan ruang spasial Saoraja Lapinceng secara vertikal berdasarkan waktu kejadiannya dalam komunikasi arsitektural.

\section{Hasil dan Diskusi}

Saoraja Lapinceng merupakan rumah Raja Balusu yang terdapat di Kecamatan Soppeng Riaja, Kabupaten Barru Sulawesi Selatan yang masih difungsikan sebagai hunian hingga saat ini. Eksistensinya tidak terlepas dari peran keluarga yang berupaya melestarikan warisan budaya leluhur. Meskipun bangunan ini masih terjaga hingga kini, akan tetapi sebagian besar aktivitas yang berlangsung didalamnya sudah tidak seperti sediakala. Fungsi bagian utama rumah ini selayaknya museum keluarga yang menjaga bentuk dan pembagian ruang spasialnya seperti aslinya. Hal ini disebabkan besarnya nilai tradisi yang perlu diturunkan kepada penerus keluarga maupun masyarakat Bugis Barru, serta menjadi saksi sejarah kerajaan Barru di masa lampau.

Berdasarkan penelusuran sejarah, penataan ruang spasial Saoraja Lapinceng secara vertikal dibagi menjadi tiga bagian, yang meliputi kepala bangunan atau pada suku bugis disebut "rakkeang", badan bangunan yang disebut "ale bola", dan kaki bangunan yang disebut "awa bola". 


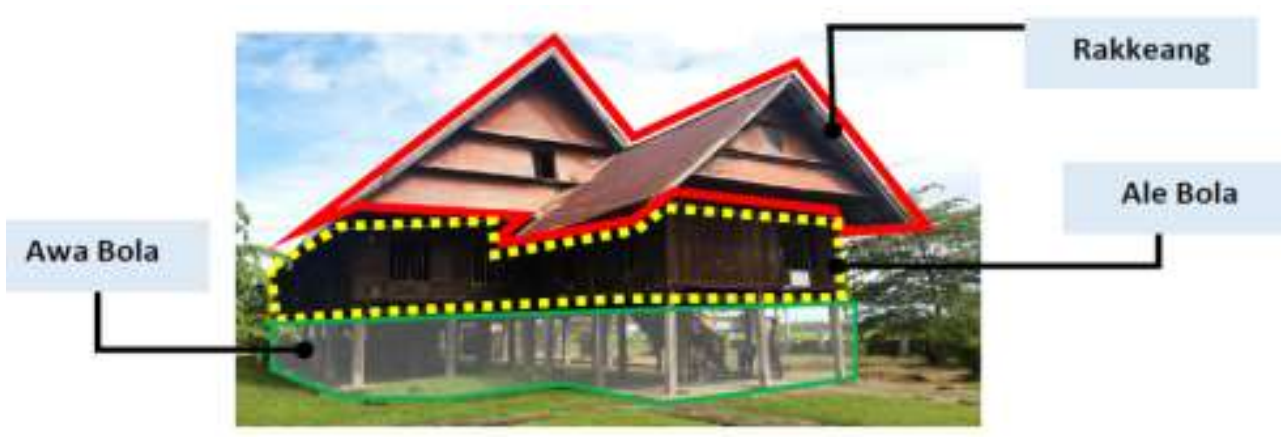

Gambar 2. Penataan ruang Saoraja Lapinceng secara vertikal

1) 'Rakkeang' atau loteng rumah dikenal sebagai bagian kepala dari Saoraja Lapinceng. Pada rumah tradisional Suku Bugis, umumnya rakkeang digunakan sebagai ruang penyimpanan hasil bumi dan cadangan makanan lainnya. Berbeda dengan fungsi rakkeang pada Saoraja Lapinceng, yang memanfaatkan rakkeang sebagai ruang tempat tinggal untuk penghuni perempuan Saoraja Lapinceng sejak mereka dilahirkan hingga saat mereka akan menikah. Aturan adat yang berlaku di Kerajaan Balusu ini melarang anak perempuan menginjakkan kaki pada bagian ruang "Ale Bola" dan "Awa Bola" sampai mereka resmi menikah. Aturan ini dimaksudkan untuk menjaga penghuni perempuan tersebut dari fitnah dan kemungkinan buruk lainnya karena perempuan merupakan salah satu harta berharga kerajaan. Perempuan merupakan makhluk yang dijunjung tinggi pada masa itu, oleh karenanya para penghuni perempuan ditempatkan di loteng rumah sebagai tempat tertinggi pada struktur bangunan untuk melakukan segala aktivitasnya.
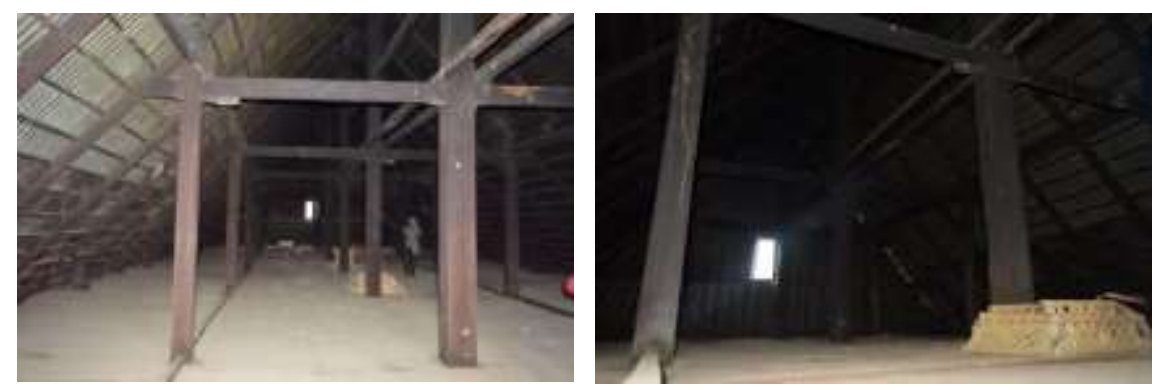

Gambar 3. Kondisi rakkeang sebagai ruang tinggal penghuni perempuan (anak gadis)

Selain difungsikan sebagai ruang tempat tinggal penghuni perempuan. Ruang ini juga digunakan sebagai tempat penyimpanan mayat penghuni rumah. Raja Balusu dan para penasehat kerajaan menganggap ruang tertinggi pada suatu rumah merupakan tempat yang paling tepat untuk mensemayamkan mayat. Hal ini didasari oleh anggapan masyarakat bahwa mayat dapat dengan mudah sampai ke surga apabila diletakkan ditempat yang tinggi. Adapun posisi terbaik penempatan mayat diletakkan didekat jendela loteng karena jendela dianggap sebagai jembatan antara dunia dan alam ghaib. Di tempat tersebut terdapat tiga balok menjorok dan mengapit pada kolom rumah. Balokbalok tersebut diperkirakan sebagai tempat atau dudukan dalam peletakan jenazah menggunakan peti. 


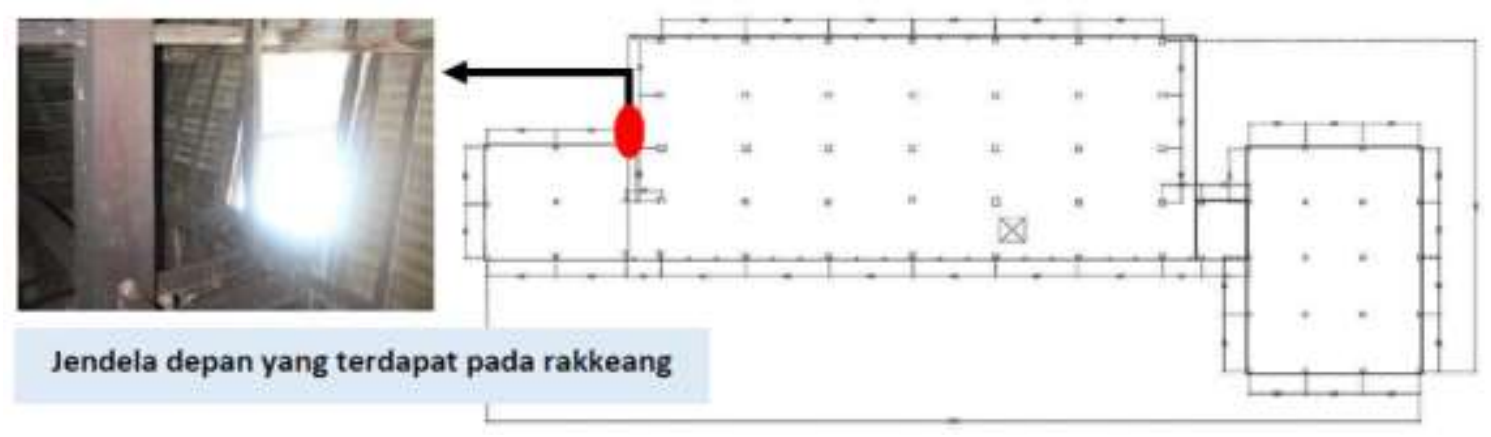

Gambar 4. Letak jendela sebagai penanda penempatan mayat

2) "Ale Bola" atau badan rumah yang merupakan bagian inti dari Saoraja Lapinceng memiliki dimensi ruang yang cukup besar yakni sekitar $35 \times 12$ meter terdiri dari serambi (lego-lego), ruang pertemuan, ruang keluarga, kamar arajang, kamar raja, kamar datu', dan dapur. Bagian ruang yang memiliki perbedaan dengan Saoraja Bugis lainnya terdapat pada fungsi ruang pertemuan dan lego-lego.

a) Ruang Pertemuan

Ruang pertemuan berfungsi sebagai tempat berkumpul para raja dan tamu undangan kerajaan. Suasana ruang pertemuan ini cukup khas dan unik karena terdapat kolom yang dipotong dengan ketinggian yang berbeda guna mencerminkan tingkat strata sosial masyarakat yang berkunjung di ruang pertemuan tersebut. Kondisi ruang pertemuan pada awalnya memiliki kolom yang utuh dan menerus, namun ruang pertemuan membutuhkan ruang bukaan yang cukup luas untuk melakukan musyawarah yang lebih efektif dan efisien sehingga beberapa kolom pada ruangan ini harus dipotong.
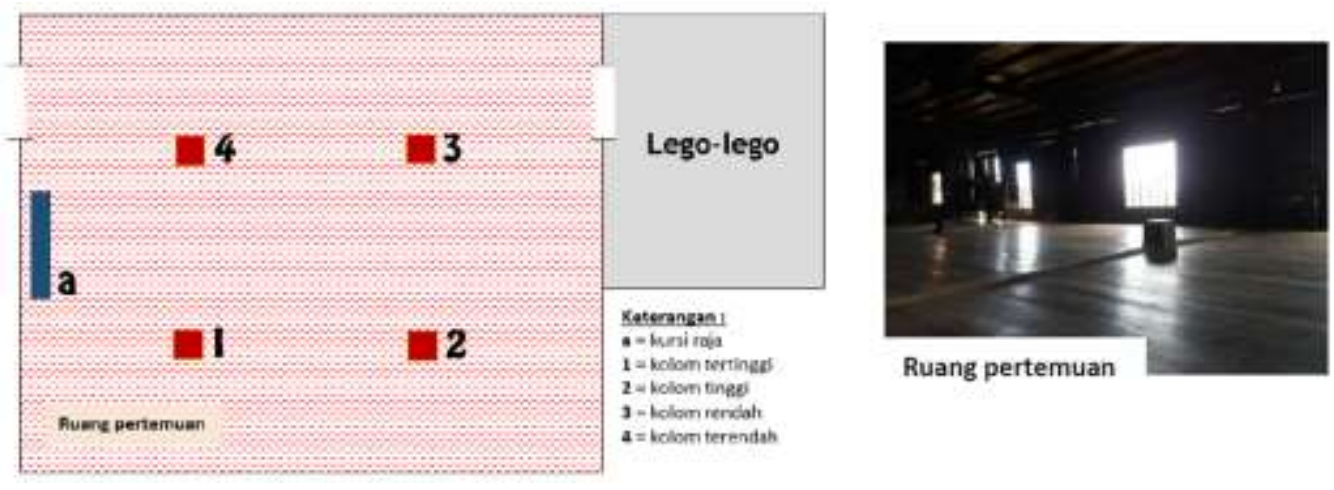

Gambar 5. Letak tingkatan kolom rumah pada ruang pertemuan

Selain itu, kolom yang terpotong juga dimaksudkan sebagai tanda pemisah golongan tamu yang hadir berdasarkan tingkat strata sosialnya. Ruang pertemuan terbagi atas empat bagian yang ditandai dengan jumlah kolom yang dipotong berdasarkan ketinggian tertentu. Kolom yang tertinggi diperuntukkan bagi golongan tertinggi setelah raja dan kolom yang terendah diperuntukkan bagi golongan rakyat jelata yang terletak paling belakang dan berdekatan dengan dapur.

b) Serambi (lego-lego)

Serambi atau lego-lego terletak pada bagian paling depan dari badan rumah tepatnya terletak diatas tangga utama. Pada bagian teras digunakan untuk menyimpan kuda milik raja maupun kuda milik para tamu kehormatan kerajaan Balusu. Peran kuda 
pada masa kerajaan adalah sebagai moda transportasi ideal yang digunakan oleh masyarakat dalam melakukan pola pergerakan dari satu tempat ke tempat lain. Oleh karena itu, kaum bangsawan memperlakukan kuda mereka dengan sangat baik. Salah satu bentuk pemeliharaannya adalah dengan memberikan ruang khusus pada bagian inti rumah atau 'ale bola' sebagai ruang penyimpanan kuda, tepatnya terletak pada ruang 'lego-lego' atau serambi rumah. Maka dari itu, untuk membedakan tingkat strata sosial kaum bangsawan dan kaum pribumi dapat dilihat dan diidentifikasi dari fungsi lego-lego atau serambi tersebut.

3) "Awa Bola" atau kolong rumah dikenal sebagai bagian kaki dari bangunan. Bagian ini berada diantara lantai ruang ale bola dan tanah. Ukuran ketinggian ruang di awa bola Saoraja Lapinceng ditentukan berdasarkan pada tinggi orang yang sedang menunggang kuda, karena fungsinya sebagai ruang penyimpanan kuda tamu kerajaan sehingga ketinggian ruangnya harus disesuaikan dengan ketinggian pengguna ruang tersebut. Selain itu, "awa bola" digunakan sebagai tempat menyimpan ternak dan ruang penyimpanan peralatan pertanian, perkebunan, perikanan dan lain sebagainya. Fungsinya juga cukup penting untuk mendukung dan melengkapi rangkaian kebutuhan dan aktifitas penghuni rumah.
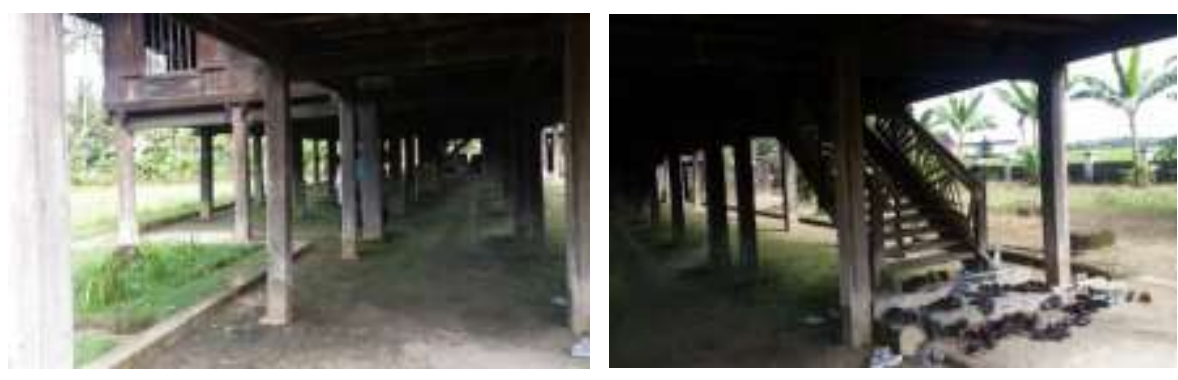

Gambar 6. Kondisi awa bola Saoraja Lapinceng

Dikatakan sebagai kaki rumah karena ruang tanpa dinding ini memiliki jumlah kolom yang banyak sehingga menyerupai seperti kaki. Demikian halnya dengan fungsinya sebagai ruang penggerak dan pendukung segala aktivitas perekonomian penghuninya. Sehingga kolong rumah juga memiliki andil yang cukup besar dalam proses kehidupan yang berlangsung pada Saoraja Lapinceng.

\section{Simpulan}

Penataan ruang spasial masyarakat Bugis di Kabupaten Barru secara vertikal dibagi atas tiga bagian, yaitu : "rakkeang" atau loteng rumah, digunakan sebagai tempat tinggal untuk penghuni perempuan sejak mereka dilahirkan hingga melepaskan status lajang. Perempuan merupakan makhluk yang dijunjung tinggi pada masa Kerajaan Balusu, oleh karena itu para penghuni perempuan ditempatkan di loteng rumah sebagai tempat tertinggi pada struktur bangunan untuk melakukan segala aktivitasnya. Sedangkan "ale bola" digunakan sebagai ruang inti dimana terdapat ruang privasi raja, ruang pertemuan hingga ruang khusus untuk penyimpanan kuda.

Penataan ruang dan penerapan fungsi ruang didalam Saoraja Lapinceng sepenuhnya dimaksudkan untuk membuat sekat pemisah tiap tingkatan strata sosial masyarakat Barru kala itu. Kemudian "awa bola" atau kolong rumah dikatakan sebagai kaki rumah karena ruang tanpa dinding ini memiliki jumlah kolom yang banyak sehingga menyerupai seperti kaki. Demikian pula dengan fungsi "awa bola" sebagai ruang 
penggerak dan pendukung segala aktivitas perekonomian penghuninya. Berdasarkan pembagian tersebut, diketahui bahwa tolak ukur dalam penataan ruang spasial Saoraja Lapinceng secara vertikal ditentukan oleh status sosial dan gender penghuninya.

\section{Daftar Pustaka}

Abdullah, H. (1985), Manusia Bugis Makassar, Intidayu Press, Jakarta.

Abidin, A.Z. dan Sabang, S. (2003), Nilai Budaya Siri', Pesse, Were, dan Konsep Demokrasi Kerajaan Wajo sebagai Masukan Pelaksanaan Ekonomi, Paper, Arsip Pemerintah Kabupaten Wajo.

Antoniades, Antony C. (1992). Poetic of Architecture: Theory of Design. New York: Van Nostr and Reinhold.

Creswell, J.W. (2008). Research Design: Qualitative, Quantitative, and Mixed Methods Approaches. California: Sage Publications, Inc.

Daeng, H.J. (2008), Manusia, Kebudayaan dan Lingkungan, Tinjauan Antropologis, Pustaka Pelajar, Yogyakarta.

Darjosanjoto, Endang Titi Sunarti. (2012). Penelitian Arsitektur di Bidang Perumahan dan Permukiman. Surabaya: ITS press.

Groat, L. \& Wang, D. (2002). Architectural Research Methods. New York: John Wiley \& Sons. Inc.

Lang, Jon. (1994). Urban Design The American Experience;Van Nostrand Reinhold: New York.

Poerwanto, H. (2008), Kebudayaan dan Lingkungan, dalam Perspektif Antropologi, Pustaka Pelajar, Yogyakarta.

Rapoport, A. (1969), House Form and Culture, Prentice-Hall, Inc, Englewood Cliffs, N.J., New York.

Robinson, K. \& Paeni, M., (2005), Tapak-Tapak Waktu: Kebudayaan, Sejarah, dan Kehidupan Sosial di Sulawesi Selatan, Ininnawa, Makassar.

Saliya, Y. (2003). Arsitektur Sebagai Bahasa: Percobaan ke Arah Epistomologi. Perjalanan Malam Hari. Bandung: Ikatan Arsitektur Indonesia \& Lembaga Sejarah Arsitektur Indenesia.

Saliya, Y. (2003). Mencoba Menghayati Arsitektur. Perjalanan Malam Hari. Bandung: Ikatan Arsitektur Indonesia \& Lembaga Sejarah Arsitektur Indenesia.

Suparlan, Parsudi. (1999). Kemajemukan, Hipotesis Kebudayaan Dominan, dan Kesukubangsaan. Jurnal Antropologi Indonesia no.58.

Tang, Mahmud. (1996). Aneka Ragam Pengaturan Sekuritas Sosial di Bekas Kerajaan Berru, Sulawesi Selatan, ISBN 90-5485-594-0, Grafisch Service Centrum Van Gils B.V, Wageningen.

Wan Ismail, Wan Hashimah. (2012). Cultural Determinants in the Design of Bugis Houses. Journal Procedia - Social and Behavioral Sciences: Elsevier, sciencedirect, 50 (2012) $771-780$.

Wasilah, Josef Prijotomo, Murni Rachmawaty. (2012). Filosofi Tipologi Bentuk dan Ekspresi Arsitektur Rumah Tradisional Mamasa, Seminar Semesta Arsitektur Nusantara (SAN) 121212. Ref No: (B.1.5) 